\title{
EFFICIENCY OF HOSPITALS IN THE CZECH REPUBLIC
}

\author{
Jana Votápková, Lenka Št’astná*
}

\begin{abstract}
:
The paper estimates cost efficiency of 99 general hospitals in the Czech Republic during 2001-2008 using the Stochastic Frontier Analysis. We control for determinants of the inefficiency and found that bigger, not-for-profit and teaching hospitals tend to be less efficient, as well as hospitals in municipalities with a larger share of the elderly. Small hospitals, hospitals in bigger municipalities and hospitals in regions where hospital competition is tense tend to be more efficient.
\end{abstract}

Keywords: efficiency, hospitals, stochastic frontier analysis.

JEL Classification: D24, I11

\section{Introduction}

The world economic crisis has put all governments under pressure, which resulted, in large scale saving provisions. Tightening budget and increasing pressures on the efficiency of public spending represent currently major challenges also for the Czech government. Health care provision is not an exception. Public spending on health care in the Czech Republic is still enormous. Out of CZK 291,956 million (7.96\% GDP), which was expended on health care in 2010, general government expenditure amounted to $83.3 \%$ (UZIS, 2011). Debates about inefficiency of the Czech health care system have resulted in a number of reforms. The major ones include increasing private involvement on health care funding and privatization of hospitals. Indicators of relative efficiency are thus necessary to gauge whether the cost-containment efforts were successful.

The first empirical literature on measuring efficiency of hospitals appeared in the 1980s (e.g. Nunamaker, 1983; Sherman, 1984). Since the 1990s, measuring efficiency of hospitals as well as examining its determinants has been a major interest of health care economics all around the world. A number of studies analyzed US data (Zuckerman et al., 1994; Rosko \& Chilingerian, 1999; Vitaliano \& Toren, 1996; Rosko, 2001); in Europe, Prior (1996) analyzed efficiency of Spanish hospitals and Magnussen (1996) analyzed Norwegian hospitals. Efficiency analysis of hospital sector spread to many other countries after 2000 (see Hofmarcher et al. (2002) for Austria, Farsi \& Filippini (2004) for Switzerland,

* Institute of Economic Studies, Faculty of Social Sciences, Charles University, Opletalova 26, Prague, CZ-110 00 (votapkovaj@fsv.cuni.cz).

Authors are thankful to Martin Gregor, Libor Dušek and the ETPM seminar participants at the Institute of Economic Studies, Charles University in Prague, for their helpful comments and suggestions. Financial support by SVV 267 504, MSMT 0021620841 and GAUK 910915 Grants are gratefully acknowledged. 
Jacobs (2001) for Great Britain). The list is not exhaustive, more examples can be found in overview studies by Worthington (2004) or Hollingsworth (2008).

Individual efficiency scores are influenced by the characteristic features of each unit examined. When not accounted for, lower efficiency scores are taken as inefficiency even though caused by the environmental factors. Factors which may affect inefficiency of a hospital include size, ownership type, or location. Zuckerman et al. (1994) is considered to be a pioneering work in the examination of determinants of inefficiency, later further studies emerged, e.g. (Rosko \& Chilingerian, 1999; Rosko, 2001; Folland \& Hofler, 2001).

The high number of empirical studies dealing with hospital efficiency and its determinants abroad supports the necessity to deal with the subject matter. Unfortunately, a similar analysis of hospital efficiency is scarce or even missing in former communist countries including the Czech Republic. An analysis of efficiency of hospitals in the Czech Republic has been carried out only in Dlouhý et al. (2007) and Novosadová \& Dlouhý (2007) who estimated technical efficiency of a cross-sectional sample of 22 Czech hospitals in 2003 and 119 hospitals in 2005, respectively, using a non-parametric approach (Data Envelopment Analysis). However, in neither of the studies, the effect of environmental factors on inefficiency was taken into account.

Our analysis contributes to the field of missing research. In order to measure efficiency of Czech hospitals, we employ the Stochastic Frontier Analysis, a parametric method that constructs the frontier and decomposes the entire deviation from the frontier into inefficiency and statistical noise. We also estimate the effect of determinants on inefficiency. The estimation of inefficiency and its determinants is carried out in one step to prevent left-out variable bias (Greene, 2003) and a bias resulting from contradictory distributional assumptions (Coelli et al., 2005), which may result in a two-step estimation. We try to answer the following questions: (i) what is relative efficiency of Czech hospitals? (ii) which exogenous factors, such as hospital status or geographical setting, influence the estimated inefficiency scores and what effect they have?

The paper analyzes inpatient care in 99 Czech hospitals in the period 2001-2008; only general hospitals are subject of the analysis. We estimate a Cobb-Douglas cost function in which total inpatient cost is used as the dependent variable. Inpatient days (severity of cases is controlled for), doctor/bed and nurse/bed ratios and salaries are used as independent variables. The paper analyzes the effect of various determinants upon inefficiency - size of the hospital, for-profit/not-for-profit status, teaching status, population size and share of the elderly in the municipality where the hospital is situated, as well as the number of hospitals in the region.

All determinants proved to have a significant effect on inefficiency. Teaching status decreases efficiency of Czech hospitals since additional costs related to teaching status, such as teaching material and special personal costs are incurred. Small hospitals tend to be more efficient than big hospitals; hospitals with for-profit status are more efficient, as well as hospitals in bigger cities. However, larger share of elderly people makes hospitals 
less efficient. Larger number of hospitals in the region seems to put pressure on hospitals to increase their efficiency.

This paper is organized as follows. Section 2 provides theoretical background for efficiency analysis and describes the estimation methodology. Section 3 presents the dataset and introduces variables employed. Section 4 presents results of the efficiency estimations; effects of determinants on inefficiency are analyzed and efficiency scores obtained are discussed. Section 5 concludes and provides motivation for further research.

\section{Methodology}

When estimating efficiency of hospitals in the Czech Republic, the Stochastic Frontier Analysis was employed (further SFA). It is a stochastic benchmarking parametric technique, the cross-sectional variant of which was first proposed by Aigner et al. (1977) and Meeusen \& van den Broeck (1977) independent of each other.

The model is specified as a cost function. Cost function is more convenient to be used in health care applications and thus such a specification was also often encountered in the literature (Rosko, 2001; Rosko \& Chilingerian, 1999; Jacobs, 2001; Yong \& Harris, 1999; Zuckerman et al., 1994). The function takes a Cobb-Douglas form ${ }^{1}$ :

$$
\ln c_{i t}=\beta_{0}+\sum_{s=1}^{S} \beta_{s} \ln y_{i t}^{s}+\sum_{m=1}^{M} \beta_{m} \ln w_{i t}^{m},
$$

where $c_{i t}$ corresponds to total costs for the decision making unit $i\left(\mathrm{DMU}_{i}\right), i \in \mathrm{N}$, $\mathbf{N}=(1, \ldots, n)$ at time $t \in \mathrm{T},\left(\mathrm{y}^{1}, \ldots, \mathrm{y}^{\mathrm{s}}\right)$ are output variables and $\left(\mathrm{w}^{1}, \ldots, \mathrm{w}^{\mathrm{m}}\right)$ denote input prices.

The panel data version of the inefficiency model will take the form proposed by Battese \& Coelli (1995):

$$
\ln c_{i t}=f\left(\boldsymbol{y}_{i t}, \boldsymbol{w}_{i t}, \boldsymbol{\beta}\right)+v_{i t}+u_{i t},
$$

where $\boldsymbol{y}_{i t}$ is a $1 \times s$ vector of outputs of $\mathrm{DMU}_{i}$ at time $t$; is $\boldsymbol{w}_{i t}$ a $1 \times m$ vector of input prices and $\boldsymbol{\beta}$ is a vector of unknown parameters to be estimated. $v_{i t}$ is a random variable which is assumed to be i.i.d., $v_{i t} \sim N\left(0, \sigma_{v}^{2}\right)$ and independent of $u_{i t}$. The inefficiency effect $u_{i t}$ is specified as

$$
u_{i t}=\delta z_{i t}+\omega_{i t}
$$

where $\boldsymbol{z}_{i t}$ is a $\mathrm{p} \times 1$ vector of determinants of inefficiency of $\mathrm{DMU}_{i}$ at time $t, \delta$ is a vector of parameters to be estimated, $\omega_{i t}$ is a random variable defined by truncation of the normal distribution with zero mean and variance $\sigma^{2}$, such that the truncation point is $-\delta \boldsymbol{z}_{i t}$, i.e. $\omega_{i t}, \geq-\delta \boldsymbol{z}_{i t}$. Inefficiency $u_{i t}$ is thus of non-negative truncation of the $N\left(\delta \boldsymbol{z}_{i t}, \sigma_{u}^{2}\right)$ distribution. In other words, determinants of inefficiency influence the mean of the truncated normal distribution.

1 A less restrictive translog function was tested but suffered from over-specification and fit of the model was worse. 
Since the model will be estimated in one step using maximum likelihood ${ }^{2}$, we will parameterize similar to Battese \& Corra (1977). A joint density function for both inefficiency and the random noise will be created and $\sigma_{v}^{2}$ and $\sigma_{u}^{2}$ will be replaced with $\sigma^{2}=\sigma_{v}^{2}+\sigma_{u}^{2}$. At the same time parameter $\gamma$ will be specified such that

$$
\gamma=\frac{\sigma_{u}^{2}}{\sigma_{v}^{2}+\sigma_{u}^{2}} .
$$

\section{Data}

Panel data on 99 general hospitals in the Czech Republic for the period of 2001-2008 were analyzed. From 192 Czech hospitals in 2008 (UZIS, 2009), 48 \% was excluded for various reasons. Some of them were specialized hospitals or provided care only in a few wards (20\%), some were closed, incorporated into larger systems or transformed, and some hospitals did not report data for certain years. ${ }^{3}$

The final unbalanced panel consists of 661 observations. The number of observations in each year varies from 76 in 2001 to 90 in 2006. The list of hospitals analyzed in this paper is provided in Table A1 in Appendix. Most of the hospitals treat up to 20,000 patients a year on average. There are two very big hospitals in the sample treating more than 70,000 patients a year. The third biggest hospital cures "only" 54,700 patients a year. The distribution of hospitals in terms of size is depicted in Figure $1 .{ }^{4}$

Efficiency was estimated with Coelli's (1996) SFA software FRONTIER Version 4.1.

2 SFA estimation of inefficiency in a panel relies upon the unobservable being predicted. It is obtained as a conditional expectation upon the observed value. Using maximum likelihood (subject to some sign changes, the log likelihood function of the cost function is to be found in Battese $\&$ Coelli, 1992), only $\varepsilon_{i t}=v_{i t}+u_{i t}=y_{i t}-\beta x_{i t}$ can be directly observed. Consequently, time and DMU-specific inefficiency $u_{i t}$ is conditioned upon the observed overall residual as in Jondrow et al. (1982) or Battese \& Coelli (1988): $E\left[u_{i t} \mid \varepsilon_{i t}\right]=\frac{\sigma \lambda}{1+\lambda^{2}}\left[\frac{\varnothing\left(a_{i t}\right)}{1-\left(a_{i t}\right)}-a_{i t}\right]$ where $\lambda=\frac{\sigma_{u}}{\sigma_{v}} ; a_{i t}=\mp \frac{\varepsilon_{i t} \lambda}{\sigma}$; $\varnothing\left(a_{i t}\right)$ is the standard normal density evaluated at $a_{i t} ; \Phi\left(a_{i t}\right)$ is the standard normal cumulative distribution function evaluated at $a_{i t}$.

3 In terms of the amount of beds, 99 hospitals covered in the analysis account for 50,304 beds out of 63,263 beds in total (192 hospitas), i.e. almost $80 \%$ of beds are included in the analysis.

4 Data on individual hospitals were obtained from the Institute of Health Information and Statistics of the Czech Republic (UZIS, 2004-2005, 2001-2008). Most of the determinants of inefficiency was obtained from the Czech Statistical Office, Regional Yearbooks (www.czso.cz), ownership and profit status was obtained from the Registry of Companies in the Czech Republic (www.obchodnirejstrik.cz). Data expressed in monetary terms, i.e. costs and salaries, were adjusted for inflation using annual growth rate of inflation with 2001 representing the base year. 
Figure 1

Size Distribution of Hospitals

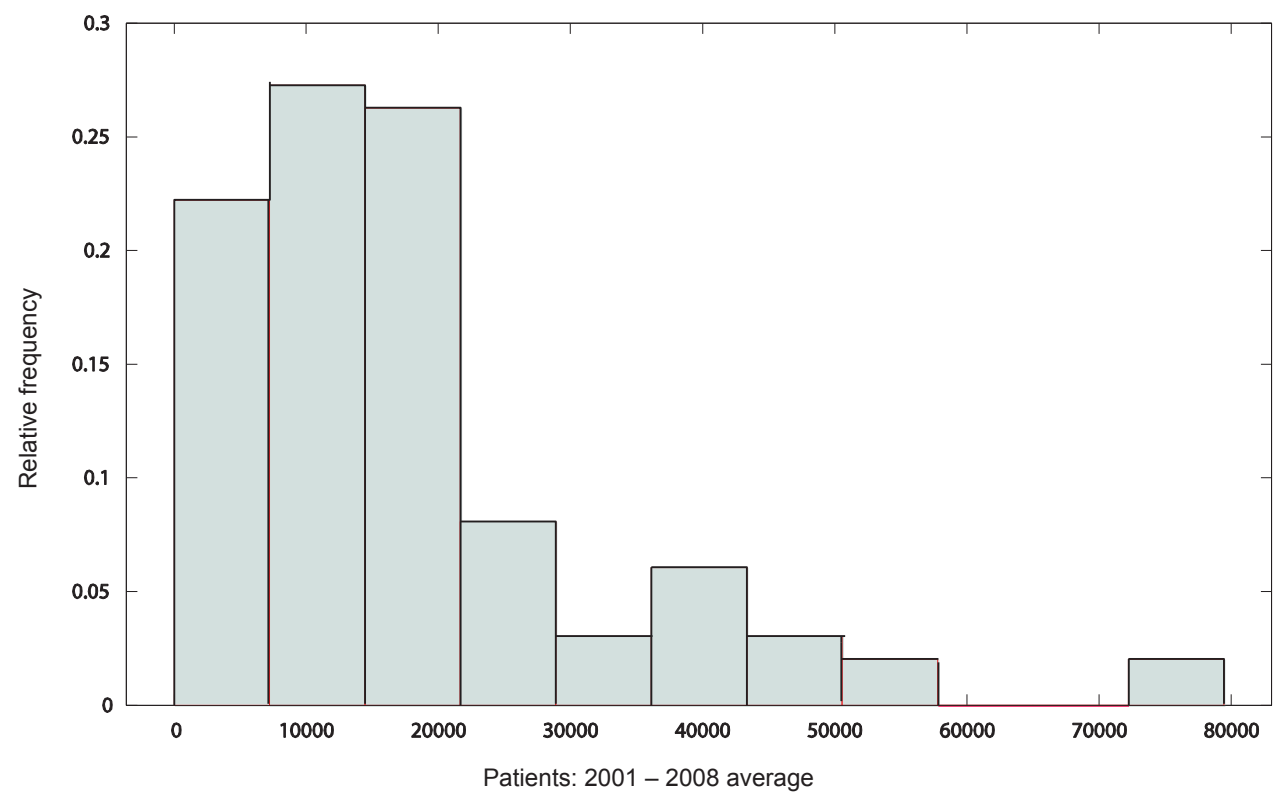

\subsection{Cost function}

In this paper, only inpatient care is considered. Not only were data on outpatient output variables not available but Yong \& Harris (1999) also found out that inpatient care consumes majority of hospital resources. These findings are supported by the Czech data (UZIS, 2004-2005), which disaggregate hospital costs into inpatient, outpatient, transport costs and non-medical expenses. Inpatient costs of Czech hospitals are on average around $50 \%$ of total costs. Of the remaining categories, outpatient care accounts for between $15-20 \%$ of total costs.

Since we estimate a cost function and thus measure cost efficiency, total operating inpatient costs (denoted as costs in the analysis) constitute the dependent variable. It was calculated as multiplication of operating costs per patient day, the number of admissions and the average length of stay. ${ }^{5}$

Since it is technically impossible to measure health output as an increment to patient health status, in all hospital efficiency studies intermediate outputs were used instead.

$5 \quad$ All these variables are available from UZIS (2001-2008) which calculates operating costs per patient day as: $\frac{1+\frac{D+J+N}{L+A}}{T}$, where $L$ are costs for inpatient care, $D$ costs for medical transport, $J$ costs for other medical care, $N$ costs for non-medical procedures, $A$ outpatient costs and $T$ the number of inpatient days. 
These include number of admissions (e.g. Zuckerman et al., 1994; Farsi \& Filippini, 2004; Hofmarcher et al., 2002) or the number of patient days (Magnussen, 1996). Having found that the correlation of the inpatient days and the number of patients is considerably high, reaching 0.98 , we use only inpatient days.

As widely claimed (Rosko \& Chilingerian, 1999; Valdmanis, 1992; Hofmarcher et al., 2002), weighting according to severity of cases is absolutely vital for the efficiency analysis. We will therefore weight the number of patient days according to the case-mix criteria as of UZIS (2005) publications, which disaggregates total inpatient days into non-operative wards (non_op_days), operative wards (op_days), intensive care (intense days) and nursing care/long-term care (nursing_days). ${ }^{6} \mathrm{We}$, however, distinguish only between nursing days and total number of non-operative, operative and intensive-care days (sum_3_days). In the preliminary analysis below, we provide reasons for summing up these three types of care.

Besides the weighted number of patient days, there are indicators of the quality of care which will be included as output variables since higher quality of care is likely to increase costs of hospitals, and at the same time, output of higher quality can be considered as more output. Quality of care was accounted for differently in the literature. Examples include mortality rates (Zuckerman et al., 1994), technology indices (Vitaliano \& Toren, 1996) or occupancy rate. Quality of care variables used in this paper will comprise per day doctor/bed and nurse/bed ratios (doctor_bed, nurse_bed), as in Frohloff (2007), based on the rationale that the more doctors/nurses attend one bed per day, the higher the quality of care is assumed to be.

To complete the cost function, input prices were included. These represent wages (salary) only. We neglect the price of capital, consistent with the definition of the dependent variable, where capital costs were excluded as well. We thus estimate a short-run cost function. Price of labour is proxied by average monthly wages for districts. Although wages of doctors and nurses are partly given by tariffs, prices of services and goods related to inpatient care purchased by a hospital reflect expensiveness of the region. ${ }^{7}$

\subsection{Determinants of inefficiency}

Inefficiency may be influenced by many external factors. The choice of variables used as potential determinants in this paper has been guided by health care studies and data availability.

6 Information on disaggregation is available also from UZIS (2004) publications, however it methodologically differs dividing inpatient days into basic care, specialized care, intensive care and nursing/long-term care. Share of intensive care and nursing/long-term care, the two categories which were kept the same in both years, were consistent (share of intensive care with correlation of 0.98 , nursing care was correlated by 0.85 between 2004 and 2005).

7 The Czech Statistical Office provides district data only till 2004. From 2005 on, data are not statistically collected anymore and only regional information is available. Therefore, for the remaining years, i.e. 2005-2008, information from 2004 was adjusted for annual growth of the average wage in the region. This approximation is considered to be sufficient for the analysis. 
Teaching hospitals (teaching) tend to reveal a different structure of services providing less of basic and more of highly specialized care, management and organization of resources (Vitaliano \& Toren, 1996, p. 165). Therefore, the presence of teaching status has been acknowledged as a very important determinant of efficiency. ${ }^{8}$

Hospitals in the sample were divided into three groups according to size since it is assumed that being of a certain size might reveal some economies or diseconomies of scale and thus influence efficiency. The logics behind is consistent with Farsi \& Filippini (2004). In this paper, hospitals were divided according to the number of patients treated to small hospitals (below 10,000, small), medium hospitals (10,000-20,000, medium) and big hospitals (above 20,000, big). All the groups contain equally 33 observations. Only the effect of small and big hospitals in the sample will be studied.

According to the economies of scale rationale, one would expect that efficiency of a hospital increases with its size. This hypothesis was proved by Zuckerman et al. (1994) and Vitaliano \& Toren (1996). On the other hand, using available beds to account for size, Yong \& Harris (1999) found out that it decreases efficiency. Yong \& Harris's findings could be explained by the presence of other costs to manage complexity of a larger scale practice, such as professional administration, information technology demands, infrastructure, etc. The mixed empirical findings suggest that size effect is regionspecific. Therefore, either of the effects might result, i.e. that size decreases inefficiency due to economies of scale, or, that size increases inefficiency due to increased costs connected with the management of complex care.

Keeping in mind transformation of many of the Czech hospitals into joint stock companies starting in 2004, ownership is expected to explain a significant portion of inefficiency because the main purpose of privatization was to curb costs and increase efficiency. Even though many Czech hospitals have been transformed into joint-stock companies, regions, district or municipalities are their major shareholders. Therefore, they are still to a large extent publicly owned.

Having carefully examined individual hospitals, it has been found that only $5 \%$ of for-profit hospitals are owned by a private entity. Hence, it is hard to uncover the effect of ownership (private versus public) for for-profit hospitals. Therefore, we aim to find effects of the not-for-profit status (not_profit), when effects of for-profit hospitals ( $95 \%$ of them are public) are compared to public not-for-profit hospitals. The hypothesis is that not-for-profit public status is associated with more inefficiency.

The remaining determinants express attributes of the environment in which the hospital is situated rather than of the hospital itself. Population size (population) is expected to

8 Some studies (e.g. Vitaliano \& Toren, 1996) included a teaching variable as a different kind of output into the cost function. We are, however, interested in how the historic mission, i.e. teaching commitment, affects the position of the hospital vis-a-vis the best practice frontier, consistent with Rosko \& Chilingerian (1999). Including a dummy variable into the cost function would preclude this kind of assessment. 
affect inefficiency. Data on population were gathered for municipalities where hospitals are situated. ${ }^{9}$

Population is expected to capture multiple effects, both positive and negative. An expected positive effect on inefficiency is connected with longer waiting times for treatments, both for outpatient preventive care as well as inpatient care. The longer the waiting times, and thus the later the illness is uncovered and treated, the lower the chance of full recovery at a reasonable cost. A positive effect on efficiency, on the other hand, is expected to be represented by the availability of more advanced and modern technologies used for diagnostics and treatments. The process of treatment thus becomes more efficient. The results are expected to depend on which of the two effects (positive or negative) is likely to overweight.

The share of the elderly population (over_65) is expressed as a proportion to the total population in the municipality. It is assumed that more people over 65 in municipality increase inefficiency of hospitals since the elderly usually require more demanding and costly treatments such as bypass, recovery after heart-attack, stroke, etc.

Competitive pressures in the hospital market is measured as the number of hospitals in the region (competition), consistent with Zuckerman et al. (1994). A higher number of hospitals is assumed to increase efficiency. The rationale is based on the assumption that if a public hospital is inefficient, its existence is threatened as it competes for government finances with other public hospitals.

Descriptive statistics of all variables is provided in Table 1. Table A2 shows a correlation matrix both of output variables and determinants.

Table 1

\section{Descriptive Statistics}

\begin{tabular}{|l|l|r|r|r|r|r|}
\hline Inputs \& outputs & No. obs. & \multicolumn{1}{|c|}{ Mean } & Median & Minimum & Maximum & Std. Dev. \\
\hline costs & 661 & $5.072 \mathrm{E}+08$ & $2.971 \mathrm{E}+08$ & $4.037 \mathrm{E}+07$ & $3.506 \mathrm{E}+09$ & $6.090 \mathrm{E}+08$ \\
\hline non op days & 661 & 68771 & 46666 & 6759 & 296140 & 59798 \\
\hline op days & 661 & 52111 & 39272 & 5124 & 227318 & 41510 \\
\hline intense days & 661 & 14318 & 7918 & 723 & 109552 & 17355 \\
\hline sum 3 days & 661 & 135200 & 93795 & 16062 & 607026 & 115660 \\
\hline nursing days & 370 & 17490 & 14937 & 3892 & 52470 & 10472 \\
\hline doctor 10 beds & 660 & 1.4728 & 1.3998 & 0.4370 & 3.7606 & 0.3878 \\
\hline nurse 10 beds & 660 & 5.3495 & 5.1632 & 2.6329 & 13.7757 & 1.0805 \\
\hline salary & 661 & 15897 & 15463 & 11894 & 24416 & 2572 \\
\hline Determinants & No. obs. & Mean & Median & Minimum & Maximum & Std. Dev. \\
\hline teaching & 661 & 0.1241 & 0 & 0 & 1 & 0.3299 \\
\hline small & 661 & 0.3147 & 0 & 0 & 1 & 0.4647 \\
\hline big & 661 & 0.3570 & 0 & 0 & 1 & 0.4791 \\
\hline not profit & 661 & 0.7216 & 1 & 0 & 1 & 0.4485 \\
\hline population & 661 & 65255 & 27544 & 3107 & 373272 & 89686 \\
\hline over 65 & 661 & 14.173 & 14.250 & 8.800 & 18.300 & 1.650 \\
\hline competition & 661 & 15.9123 & 14 & 5 & 28 & 6.7074 \\
\hline
\end{tabular}

9 Since Prague was taken as one municipality and its population thus might bias the results, the population of Prague was divided into core catchment areas of individual hospitals. 


\section{Empirical Results}

Prior to efficiency measurement, the data on output variables was thoroughly analyzed. Examining the different kinds of output (i.e. non-operative, operative, intensive, nursing patient days), a high level of correlation among the first three was discovered varying from 0.88 to 0.93 . Including all these variables in the cost function may lead to multicollinearity.

It was thus highly desirable to restructure the data in such a way to keep as much information in the data as possible to account for the output mix but also to avoid multicollinearity. Similar to Janlov (2007), the Principal Components Analysis (further PCA) (Jolliffe, 2002) was carried out to uncover the internal structure of the data. Table 2 provides the results for patient days in natural units.

The first two components express over $96.92 \%$ of information of the data. We therefore transform the four initial variables and include only two types of care. The first component loadings are assumed to express variance in the first three variables, while the second ones account for the variance in nursing days. When looking at loadings for the first component, their similarity for the three variables concerned (non-operative, operative, intensive care) is striking. Instead of multiplying the original variables by their loadings for each of the two most significant components, we can thus simply transform the data by summing up the non-operative, operative and intensive care days. Hence, only two variables - nursing days (nursing_days) and sum of the non-operative, operative and intensive care days (sum_3_days) - are included among outputs, besides others.

Table 2

Principal Components Analysis: Patient Days

\begin{tabular}{|l|r|r|r|r|}
\hline & PC1 & PC2 & PC3 & \multicolumn{1}{|c|}{ PC4 } \\
\hline Eigenvalue & 2.935 & 0.941 & 0.077 & 0.047 \\
\hline Proportion & 0.734 & 0.235 & 0.019 & 0.012 \\
\hline Cumulative & 0.734 & 0.969 & 0.988 & 1.000 \\
\hline non_op_days & 0.566 & 0.139 & 0.559 & 0.589 \\
\hline op_days & 0.568 & 0.048 & -0.797 & 0.199 \\
\hline intense_days & 0.570 & 0.119 & 0.218 & -0.783 \\
\hline nursing_days & 0.177 & -0.982 & 0.067 & -0.001 \\
\hline
\end{tabular}

\subsection{Estimation results}

In this section, we present estimation results. The cost function takes the following form:

$$
\begin{gathered}
\ln \left(\operatorname{costs}_{\mathrm{it}}\right)=\beta_{0}+\beta_{1} \ln \left(\text { sum_ }_{-} \text {ddays }_{\mathrm{it}}\right)+\beta_{2} \ln \left(\text { nursing_days }_{\mathrm{it}}\right) \\
+\beta_{3} \ln \left(\text { doctor_bed }_{\mathrm{it}}\right)+\beta_{4} \ln \left(\text { nurse_bed }_{\mathrm{it}}\right)+ \\
\beta_{5} \ln \left(\operatorname{salary}_{\mathrm{it}}\right)+v_{i t}+u_{i t}
\end{gathered}
$$


The inefficiency term is specified such that:

$$
\begin{gathered}
u_{i t}=\delta_{0}+\delta_{1} \text { teaching }+\delta_{2} \text { small }+\delta_{3} \text { big }+\delta_{4} \text { not_profit }+\delta_{5} \text { population }+ \\
\delta_{6} \text { over } 65+\delta_{7} \text { competition }+\omega_{i t}
\end{gathered}
$$

Results are provided in Table 3. All variables of the cost function are significant even at $1 \%$ level and have the expected sign. Of all the output variables, the highest elasticity was for the variable sum of non-operative, operative and intensive care days. The sum of coefficients for output variables suggests diseconomies of scale.

Table 3

\section{Estimation Results}

\begin{tabular}{|l|r|r|r|r|}
\hline & Coefficient & S.E. & t-ratio & \\
\hline$\beta_{0}$ & 6.33286 & 1.02738 & 6.164 & $* * *$ \\
\hline sum_3_days & 0.84386 & 0.03293 & 25.63 & $* * *$ \\
\hline nursing_days & 0.01676 & 0.00235 & 7.132 & $* * *$ \\
\hline doctor_bed & 0.37563 & 0.05380 & 6.982 & $* * *$ \\
\hline nurse_bed & 0.68356 & 0.06603 & 10.35 & $* * *$ \\
\hline salary & 0.45600 & 0.09724 & 4.689 & $* * *$ \\
\hline$\delta_{0}$ & 0.03765 & 0.08395 & 0.448 & \\
\hline teaching & 0.42822 & 0.05008 & 8.551 & $* * *$ \\
\hline small & -0.23717 & 0.06650 & -3.567 & $* * *$ \\
\hline big & 0.08460 & 0.04144 & 2.042 & $* *$ \\
\hline not-profit & 0.14022 & 0.04417 & 3.174 & $* * *$ \\
\hline population & $-4.98 \mathrm{E}-07$ & 0.00000 & -3.062 & $* * *$ \\
\hline over_65 & 0.00566 & 0.00424 & 1.336 & $\dagger$ \\
\hline competition & -0.00413 & 0.00268 & -1.540 & $\dagger$ \\
\hline$\sigma^{2}$ & 0.06313 & 0.00393 & 16.06 & $* * *$ \\
\hline$\gamma$ & 0.01387 & 0.00627 & 2.214 & $* *$ \\
\hline Log likelihood function & & & -24.19 & \\
\hline LR one-sided error & & & 105.16 & $* * *$ \\
\hline
\end{tabular}

Note: ${ }^{* * *}$ significance at $1 \%$ level, ${ }^{* *}$ significance at $5 \%$ level, $\dagger$ one-tail significance at $10 \%$ level.

All determinants of inefficiency proved significant. Teaching status has a positive effect on inefficiency as expected, moreover, its coefficient is the largest of all the determinants. The result thus confirms that teaching hospitals are very special in their nature. They incur specific costs connected with teaching material, facility or personnel. Additionally, size dummies indicate that being a very small hospital decreases inefficiency while being very big has a positive effect of inefficiency, even though by quite a small amount.

Hospitals with not-for-profit status tend to be more inefficient than for-profit hospitals. The result is consistent with the initial hypothesis keeping in mind that the purpose of transformation into joint-stock companies was to curb extensive costs and inefficiency. For-profit hospitals seem to manage resources in a more efficient way. 
If a hospital is situated in a bigger municipality in terms of its population, it seems to be more efficient. Population may influence inefficiency of hospitals by various channels; the occupancy rate may be higher in bigger cities and thus hospitals demonstrate more patient days; at the same time, quality which decreases because of higher occupancy rate (medical staff does not have so much time for each patient, patients do not have separate rooms), may increase through availability of better medical equipment and more advanced, effective and less costly means of treatment.

The higher the share of the elderly, the higher the inefficiency of hospitals as expected. The coefficient proved significant at $10 \%$ at one-tail distribution. The hypothesis of the negative effect on inefficiency is significantly rejected. It is consistent with the findings of Frohloff (2007) who concluded that a large share of the elderly considerably increases inefficiency of hospitals.

The sign of the coefficient for the competition variable is negative which is consistent with the initial assumption that competition exerts pressures to decrease inefficiency. The coefficient proved significant at $10 \%$ one-tail, however. We thus reject the null hypothesis of a positive effect of this variable. The same result concerning the sign of the coefficient was reached by Zuckerman et al. (1994) who measured efficiency of hospitals in the U.S., however, their coefficient proved insignificant.

The likelihood ratio test on one-sided error term, i.e. the test on the presence of the inefficiency term, is significant suggesting that the inefficiency term is highly appropriate in the analysis. Parameter is also significant, reaching the value of 0.01387 . It means that the variance of the inefficiency term takes up only about 1.3 percent of the total variance. In other words, most of the total variance of the error term is captured by the variance of the white noise rather than inefficiency.

To compare rankings of hospitals in individual years, Spearman's Rank Correlation Coefficient was calculated. The results revealed that rankings of the efficiency scores are stable over time, with the correlation coefficients varying from 0.94 to 0.99 for the successive years. Therefore, there is no loss of information when results for each hospital are averaged over time. Averaged efficiency scores are provided in Table A3.

Table 4 summarizes statistics for the whole sample as well as for size groups. ${ }^{10}$ Mean efficiency for the whole sample is slightly over 0.86 and standard deviation is around 0.13 which can also be read from Figure 2. One further notices that there is no fully efficient observation. Looking at the standard deviation, it is smaller when hospitals are divided into groups than for the overall sample. It suggests that the division was reasonable revealing a considerable homogeneity of hospitals within size groups. Interestingly, having accounted for size in the regression, differences among size groups with respect to average efficiency are apparent. Specifically, efficiency decreases as group size increases being around 0.99 for small hospitals, it falls to around 0.88 for medium hospitals and decreases to 0.72 for big hospitals.

Only efficiency results were divided. Now new benchmark was constructed. 
Table 4

Summary Statistics: Efficiency Scores

\begin{tabular}{|l|r|r|r|r|}
\hline & \multicolumn{1}{|c}{ Whole sample } & \multicolumn{1}{c|}{ Small } & \multicolumn{1}{c|}{ Medium } & \multicolumn{1}{c|}{ Big } \\
\hline Mean & 0.8634 & 0.9926 & 0.8753 & 0.7223 \\
\hline Min & 0.5007 & 0.9820 & 0.8086 & 0.5007 \\
\hline Max & 0.9972 & 0.9972 & 0.9818 & 0.8982 \\
\hline St. Dev. & 0.1328 & 0.0038 & 0.0379 & 0.1213 \\
\hline No. obs. & 99 & 33 & 33 & 33 \\
\hline
\end{tabular}

Figure 2

Distribution of Average Efficiency Scores

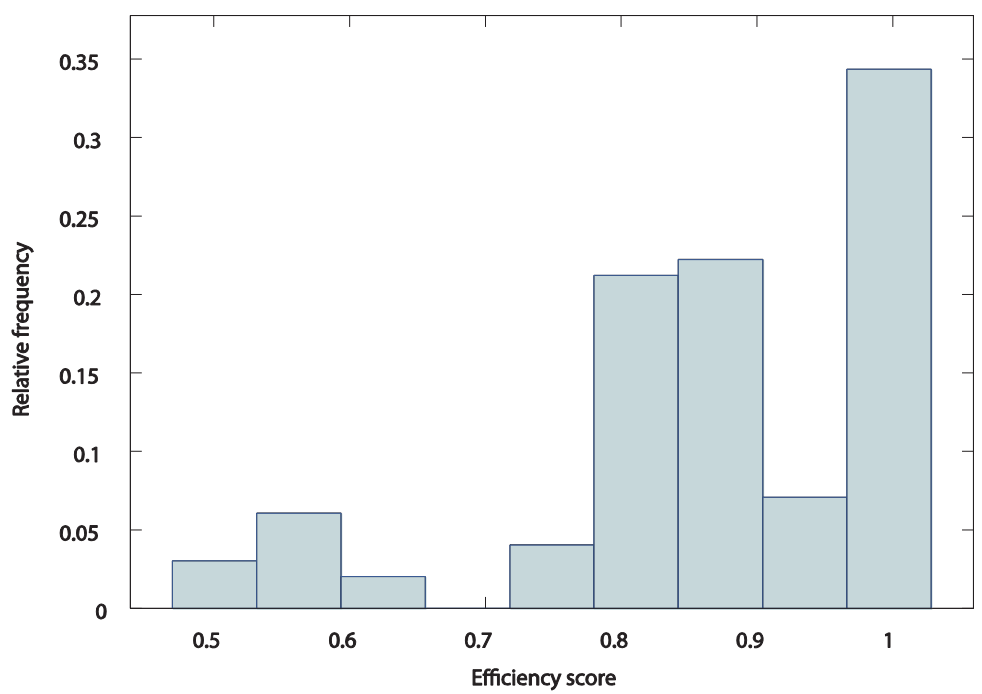

Table 5 identifies the most and least efficient hospitals in the sample. A closer scrutiny reveals that hospitals with the highest efficiency scores belong mainly to the group of small hospitals (with one exception). On the other hand, the group of the least efficient hospitals is formed exclusively by teaching hospitals ${ }^{11}$ which belong to the group of big hospitals.

Table 6 provides an overview of the number of hospitals classified in intervals corresponding to efficiency scores and analyzes the results from a different perspective. It suggests that Czech hospitals are not on average overly relatively inefficient when determinants of inefficiency are identified and taken care of. It reinforces the above-stated findings that high level of inefficiency is rather group-specific. In particular, efficiency scores for teaching hospitals are much lower compared even to other big hospitals (the score for the most efficient teaching hospital reaches 0.6086 but immediately following

11 There are 11 teaching hospitals in the Czech Republic. 
another big hospital has the score of 0.7377). It is thus expected that there might be additional variables connected only with big and teaching hospitals which influence their efficiency. This serves as motivation for further research.

Table 5

Hospitals in Top and Bottom Deciles

\begin{tabular}{|c|l|c|l|}
\hline Size & \multicolumn{1}{|c|}{ ID } & Size & \multicolumn{1}{c|}{ ID } \\
\hline 1 & Rumburk & 3 & FN Hradec Králové \\
\hline 3 & Karviná Ráj & 3 & FN Olomouc \\
\hline 1 & Brandýs n. L & 3 & FN Plzeň \\
\hline 1 & Kutná Hora & 3 & FN Královské Vinohrady \\
\hline 1 & VN Brno & 3 & FN Thomayerova \\
\hline 1 & Sedlčany & 3 & FN Na Bulovce \\
\hline 1 & Roudnice n. L & 3 & VFN Praha \\
\hline 1 & Rychnov n. Kněžnou & 3 & FN Ostrava \\
\hline 1 & Hranice & 3 & FN Motol \\
\hline 1 & Kadaň & 3 & FN Sv. Anna Brno \\
\hline
\end{tabular}

Note: The first hospital in the top (bottom) decile is the most (least) efficient in the sample. Size 1=small, 2=medium, $3=$ big hospitals. $\mathrm{FN}=$ teaching hospital, $\mathrm{VN}=$ Military hospital.

Table 6

\section{Number of Hospitals in Intervals}

\begin{tabular}{|l|c|c|c|c|c|}
\hline & Whole sample & Small & Medium & Big & Teaching \\
\hline$<0.6$ & 10 & 0 & 0 & 10 & 10 \\
\hline $0.6-0.7$ & 1 & 0 & 0 & 1 & 1 \\
\hline $0.7-0.8$ & 10 & 0 & 0 & 10 & 0 \\
\hline $0.8-0.9$ & 37 & 0 & 25 & 12 & 0 \\
\hline $0.9-1$ & 41 & 33 & 8 & 0 & 0 \\
\hline total & 99 & 33 & 33 & 33 & 11 \\
\hline
\end{tabular}

\section{Conclusion}

This paper examined cost efficiency of 99 general hospitals in the Czech Republic in the period 2001-2008. Stochastic frontier analysis was employed. Having included determinants of inefficiency into the SFA regression, we discussed efficiency results as well as effects of various environmental factors on it.

Concerning determinants, teaching status decreases efficiency since additional costs connected with teaching material, teaching staff, etc. are incurred. Small hospitals tend to be more efficient, while big hospitals tend to be less efficient. Not-for-profit status was found to decrease efficiency. These findings support reasons for the ongoing privatization process of Czech hospitals. Size of the population in the municipality where the hospital is situated was found to increase efficiency. The results thus show that the effect of more advanced, complex and efficient care in bigger cities overweight the effect of longer 
waiting times (and costly care afterwards). The share of the elderly in the population tends to decrease efficiency of hospitals. The number of hospitals in the region was found to increase efficiency, consistent with the hypothesis.

The results of the analysis reveal that Czech hospitals are not overly relatively inefficient as a whole, as differences of scores are not large. Nevertheless, it has been uncovered that inefficiency is rather group specific.

The system of Diagnostic-Related Groups, common abroad as a case mix adjustment mechanism in efficiency analyses, is currently being developed in the Czech Republic. It is expected to considerably improve the way severity of cases is accounted for and thus may help explain some inefficiency specific for large and teaching hospitals.

Moreover, the effect of the process of transformation of hospitals, rather than only ownership status, could alternatively be tested in further research.

The results of this analysis should, however, not serve as a background for immediate policy responses. It rather points out to special circumstances and provides motivation for further analysis. At the same time, it is fully acknowledged that economic analysis of Czech hospitals is not telling the whole story. It should be supplemented by surveys of satisfaction with the quality of care, etc. in order for the analysis to provide an overall picture.

\section{References}

Aigner, D., Lovell, C. A. K., Schmidt, P. (1977), "Formulation and Estimation of Stochastic Frontier Production Function Models." Journal of Econometrics, 6(1): pp.21-37.

Battese, G., Coelli, T. J. (1992), "Frontier Production Functions, Technical Efficiency and Panel Data: With Application to Paddy Farmers in India." The Journal of Productivity Analysis, 3, pp. 153-169.

Battese, G. E., Coelli, T. J. (1988), "Prediction of Firm-Level Technical Efficiencies with a Generalized Frontier Production Function and Panel Data." Journal of Econometrics, 38(3): pp. 387-399.

Battese, G. E., Coelli, T. J. (1995), "A Model for Technical Inefficiency Effects in a Stochastic Frontier Production Function for Panel Data." Empirical Economics, 20(2): pp. 325-32.

Battese, G. E., Corra, G. S. (1977), "Estimation of a Production Frontier Model: with Application to the Pastoral Zone of Eastern Australia." Australian Journal of Agricultural Economics, 21:3: pp. 169-179.

Coelli, T. J. (1996), "Frontier Version 4.1: A Computer Program for Stochastic Frontier Production and Cost Function Estimation." Working Paper 07/96. Centre for Efficiency and Productivity Analysis (CEPA), CEPA Working Papers Department of Econometrics University of New England Armidale, NSW 2351s, Australia.

Coelli, T. J., Rao, P. D., O’Donnell, C. J., Battese, G. E. (2005), An Introduction to Efficiency and Productivity Analysis. Springer, 2nd Edition.

Dlouhý, M., Jablonský, J., Novosadová, I. (2007), "Využití analýzy obalu dat pro hodnocení efektivnosti českých nemocnic." Politická ekonomie, (54)1: pp. 60-71.

Farsi, M., Filippini, M. (2004), "An Analysis of Efficiency and Productivity in Swiss Hospitals." Quaderno, N. 05-01.

Folland, S. T., Hofler, R. A. (2001), "How Reliable are Hospital Efficiency Estimates? Exploiting the Dual to Homothetic Production." Health Economics, 10(8): pp. 683-698.

Frohloff, A. (2007), "Cost and Technical Efficiency of German Hospitals - a Stochastic Frontier Analysis." Ruhr Economic Papers 0002, Rheinisch-Westfalisches Institut fur Wirtschaftsforschung, Ruhr-Universitat Bochum, Universitat Dortmund, Universitat Duisburg-Essen. 
Greene, W. (2003), "Distinguishing between Heterogeneity and Inefficiency: Stochastic Frontier Analysis of the World Health Organization's Panel Data on National Health Care Systems." Working Papers 03-10, New York University, Leonard N. Stern School of Business, Department of Economics.

Hofmarcher, M. M., Peterson, I., Riedel, M. (2002), "Measuring Hospital Efficiency in Austria - A DEA Approach." Health Care Management Science, 5: pp. 7-14.

Hollingsworth, B. (2008), "The Measurement of Efficiency and Productivity of Health Care Delivery." Health Economics, 17(10): pp. 1107-1128.

Institute of Health Information and Statistics of the Czech Republic (2011), "Ekonomické informace ve zdravotnictví 2008." Technical Report, UZIS CR, denoted UZIS (2009) in the text.

Institute of Health Information and Statistics of the Czech Republic (2011), "Zdravotnictví České republiky 2010 ve statistických údajích.” Technical Report, UZIS CR, denoted UZIS (2011) in the text.

Institute of Health Information and Statistics of the Czech Republic, Regional Offices (2001-2008), "Zdravotnictví (kraje + CR)." Technical Report, UZIS CR, denoted UZIS (2001-2008) in the text.

Institute of Health Information and Statistics of the Czech Republic, Regional Offices (20042005), "Provozně-ekonomické informace lůžkových zařízení v kraji." Technical Report, UZIS CR, denoted UZIS (2004-2005) in the text.

Jacobs, R. (2001), "Alternative Methods to Examine Hospital Efficiency: Data Envelopment Analysis and Stochastic Frontier Analysis." Health Care Management Science, 4: pp. 103-116.

Janlov, N. (2007), "Swedish Health Care Performance - Quantity versus Quality." Working Papers 2007:17, Lund University, Department of Economics.

Jolliffe, I. T. (2002), Principal Component Analysis. Springer USA.

Jondrow, J., Knox Lovell, C. A., Materov, I. S., Schmidt, P. (1982), "On the Estimation of Technical Inefficiency in the Stochastic Frontier Production Function Model." Journal of Econometrics, 19(2-3): pp. 233-238.

Magnussen, J. (1996), "Efficiency Measurement and the Operationalization of Hospital Production." Health Service Research, (31)1: pp. 21-37.

Meeusen, W., van den Broeck, J. (1977), "Efficiency Estimation from Cobb-Douglas Production Functions with Composed Error." International Economic Review, 18(2): pp. 435-44.

Nunamaker, T. R. (1983), "Measuring Routine Nursing Service Efficiency: A Comparison of Cost per Patient Day and Data Envelopment Analysis Models." Health Service Research, 18: pp. 183-205.

Novosadova, I., Dlouhy, M. (2007), "Hodnotenie technickej efektívnosti nemocníc a odmeňovanie zdravotníkov." Ekonomicky casopis, 55 (8), pp. 762-782.

Prior, D. (1996), "Technical Efficiency and Scope Economics in Hospitals." Applied Economics, 28: pp. 1295-1301.

Rosko, M. D. (2001), "Cost Efficiency of US Hospitals: a Stochastic Frontier Approach." Health Economics, 10(6): pp. 539-551.

Rosko, M. D., Chilingerian, J. A. (1999), "Estimating Hospital Inefficiency: Does Case Mix Matter?" Journal of Medical Systems, (23)1: pp. 57-71.

Sherman, D. H. (1984), "Hospital Efficiency Measurement and Evaluation. Empirical Test of a New Technique." Medical Care, 22, pp. 922-938.

Valdmanis, V. (1992), "Sensitivity Analysis for DEA Models an Empirical Example Using Public vs. NFP Hospitals." Journal of Public Economics, 48, pp. 185-205.

Vitaliano, D. F., Toren, M. (1996), "Hospital Cost and Efficiency in a Regime of Stringent Regulation." Eastern Economic Journal, (22)2: pp. 161-175.

Worthington, A. C. (2004), "Frontier Efficiency Measurement in Health Care: A Review of Empirical Techniques and Selected Applications." Med Care Res Rev, 61(2): pp. 135-170.

Yong, K., Harris, A. (1999), "Efficiency of Hospitals in Victoria under Casemix Funding: A Stochastic Frontier Approach." Working Paper 92. Centre for Health Program Evaluation.

Zuckerman, S., Hadley, J., lezzoni, L. (1994), "Measuring Hospital Efficiency with Frontier Cost Functions." Journal of Health Economics, 13, pp. 255-280. 


\section{Appendix}

Table A1

\section{Overview of Hospitals}

\begin{tabular}{|c|c|c|c|}
\hline ID & Name & ID & Name \\
\hline 1 & Nemocnice České Budějovice, a.s. & 51 & NsP Nový Jičín, p.o. \\
\hline 2 & Nemocnice Český Krumlov, a.s. & 52 & Bílovecká nemocnice, a.s. \\
\hline 3 & Nemocnice Jindřichův Hradec, a.s. & 53 & Slezská nemocnice v Opavě, p.o. \\
\hline 4 & Nemocnice Písek, a.s. & 54 & FNsP Ostrava \\
\hline 5 & Nemocnice Prachatice, a.s. & 55 & Městská nemocnice Ostrava, p.o. \\
\hline 6 & Nemocnice Strakonice, a.s. & 56 & Nemocnice Havlíčkův Brod, p.o. \\
\hline 7 & Nemocnice Tábor, a.s. & 57 & Nemocnice Jihlava, p.o. \\
\hline 8 & Fakultní nemocnice Hradec Králové & 58 & Nemocnice Pelhřimov, p.o. \\
\hline 9 & Oblastní nemocnice Jičín, a.s. & 59 & Nemocnice Třebíč, p.o. \\
\hline 10 & Oblastní nemocnice Náchod, a.s. & 60 & Nemocnice Nové město na Moravě, p.o. \\
\hline 11 & Oblastní nemocnice Rychnov nad Kněžnou, a.s. & 61 & Domažlická nemocnice, a.s. \\
\hline 12 & Oblastní nemocnice Náchod, a.s. Opočno & 62 & Klatovská nemocnice, a.s. \\
\hline 13 & Městská nemocnice, a.s. Dvůr Králové n. L. & 63 & Nemocnice Sušice, o.p.s. \\
\hline 14 & Oblastní nemocnice Trutnov, a.s. & 64 & Fakultní nemocnice Plzen̆ \\
\hline 15 & Nemocnice Mariánské Lázně, s.r.o. & 65 & Stodská nemocnice, a.s., Stod \\
\hline 16 & NsP Česká Lípa, a.s. & 66 & Rokycanská nemocnice, a.s. \\
\hline 17 & Nemocnice Jablonec nad Nisou, p.o. & 67 & Krajská zdravotní, a.s. - nemocnice Děčín \\
\hline 18 & Krajská nemocnice Liberec, a.s. & 68 & Lužická nemocnice a poliklinika, a.s. Rumburk \\
\hline 19 & Nemocnice Frýdlant, s.r.o. & 69 & Krajská zdravotní, a.s. - nemocnice Chomutov, o.z. \\
\hline 20 & Masarykova městská nemocnice Jilemnice & 70 & Nemocnice Kadaň, s.r.o. \\
\hline 21 & Panochova nemocnice Turnov, s.r.o. & 71 & Podřipská NsP Roudnice n. Labem, s.r.o. \\
\hline 22 & NsP Semily, p.o. & 72 & Krajská zdravotní, a.s. - nemocnice Most, o.z. \\
\hline 23 & Fakultní nemocnice U sv. Anny, Brno, p.o. & 73 & Krajská zdravotní, a.s. - nemocnice Teplice, o.z. \\
\hline 24 & Nemocnice Milosrdných Bratří, p.o. Brno & 74 & Krajská zdravotní, a.s. - Masarykova nemocnice Ústí n. L., o.z. \\
\hline 25 & Fakultní nemocnice Brno & 75 & Nemocnice Rudolfa a Stefanie Benešov, a.s. \\
\hline 26 & Vojenská nemocnice Brno, p.o. & 76 & NH Hospitals, s.r.o. Nemocnice Hořovice \\
\hline 27 & Nemocnice Ivančice, p.o. & 77 & Oblastní nemocnice Kladno, a.s. \\
\hline 28 & Nemocnice Břeclav, p.o. & 78 & Nemocnice Slaný, p.o. \\
\hline 29 & Městská nemocnice Hustopeče, p.o. & 79 & ON Kolín, a.s. \\
\hline 30 & Nemocnice T GM Hodonín, p.o. & 80 & Nemocnice Kutná Hora, s.r.o. \\
\hline 31 & Nemocnice Kyjov, p.o. & 81 & Mělnická zdravotní, a.s., NsP Mělník \\
\hline 32 & Nemocnice Vyškov, p.o. & 82 & ON Mladá Boleslav, a.s. \\
\hline 33 & Nemocnice Znojmo, p.o. & 83 & PP Hospitals, s.r.o. Nemocnice Brandýs nad Labem \\
\hline 34 & Jesenická nemocnice, s.r.o. & 84 & Oblastní nemocnice Příbram, a.s. \\
\hline 35 & FN Olomouc & 85 & MEDITERRA - Sedlčany, s.r.o. \\
\hline 36 & Vojenská nemocnice, Olomouc, Klášterní Hradisko & 86 & PRIVAMED Healthia, s.r.o. NsP Rakovník \\
\hline 37 & Středomor. nemocniční, a.s. - nem. Šternberk & 87 & Nemocnice Na Františku s poliklinikou \\
\hline 38 & Středomor. nemocniční, a.s. - nem. Prostějov & 88 & Všeobecná fakultní nemocnice v Praze \\
\hline 39 & Středomor. nemocniční, a.s. Přerov & 89 & Fakultní Thomayerova nemocnice s poliklinikou \\
\hline 40 & Nemocnice Hranice, a.s. & 90 & Nemocnice na Homolce \\
\hline 41 & Chrudimská nemocnice, a.s. & 91 & Fakultní nemocnice Motol \\
\hline 42 & Pardubická krajská nemocnice, a.s. & 92 & Fakultní nemocnice na Bulovce \\
\hline 43 & Svitavská nemocnice, a.s. & 93 & Ústřední vojenská nemocnice, Praha 6 \\
\hline 44 & Nemocnice Krnov, p.o. & 94 & Fakultní nemocnice Královské Vinohrady \\
\hline 45 & Nemocnice ve Frýdku-Místku, p.o. & 95 & Kroměřížská nemocnice, a.s. \\
\hline 46 & Nemocnice Třinec, p.o. & 96 & Uherskohradišt'ská nemocnice, a.s. \\
\hline 47 & Nemocnice s poliklinikou Karviná-Ráj, p.o. & 97 & Vsetínská nemocnice, a.s. \\
\hline 48 & Nemocnice s poliklinikou Haviŕov, p.o. & 98 & Nemocnice Valašské Meziř́čí, a.s. \\
\hline 49 & Bohumínská městská nemocnice, a.s. & 99 & Krajská nemocnice T. Bati, a.s. Zlín \\
\hline 50 & Karvinská hornická nemocnice, a.s. & & \\
\hline
\end{tabular}

Note: Name valid in the year 2008. 


\begin{tabular}{|r|c|c|c|c|c|c|c|c|c|c|r|r|r|r|}
\hline$(1)$ & $(2)$ & $(3)$ & $(4)$ & $(5)$ & $(6)$ & $(7)$ & $(8)$ & $(9)$ & $(10)$ & $(11)$ & $(12)$ & \\
\hline 1 & 0.2 & 0.3359 & 0.3641 & 0.4184 & 0.792 & -0.543 & 0.7472 & 0.3064 & 0.6564 & 0.3024 & 0.207 & sum_3_days (1) \\
\hline & 1 & -0.041 & -0.103 & -0.033 & 0.238 & -0.252 & 0.2062 & 0.0769 & 0.2143 & -0.138 & -0.163 & nursing_days (2) \\
\hline & & 1 & 0.6586 & 0.5261 & 0.319 & -0.231 & 0.1731 & 0.0662 & 0.3019 & 0.2623 & 0.164 & doctor_bed (3) \\
\hline & & & 1 & 0.4157 & 0.307 & -0.285 & 0.2296 & 0.0638 & 0.3611 & 0.2697 & 0.158 & nurse_bed(4) \\
\hline & & & 1 & 0.482 & -0.134 & 0.2961 & -0.027 & 0.4478 & 0.4357 & 0.438 & salary (5) \\
\hline & & & & 1 & -0.255 & 0.505 & 0.2337 & 0.6352 & 0.3526 & 0.256 & teaching (6) \\
\hline & & & & & 1 & -0.505 & -0.328 & -0.297 & -0.066 & -0.067 & small (7) \\
\hline & & & & & & 1 & 0.2937 & 0.4456 & 0.0891 & 0.118 & big (8) \\
\hline & & & & & & & 1 & 0.2735 & -0.063 & 0.184 & not_profit (9) \\
\hline & & & & & & & & 1 & 0.3355 & 0.332 & population (10) \\
\hline & & & & & & & & & & 1 & 0.071 & over_65 (11) \\
\hline & & & & & & & & & & & 1 & competition (12) \\
\hline
\end{tabular}


Table A3

Efficiency Scores and Ranks

\begin{tabular}{|c|c|c|c|c|c|c|c|}
\hline Size & ID & Efficiency & Rank & Size & ID & Efficiency & Rank \\
\hline 3 & 1 & 0.8401 & 65 & 2 & 51 & 0.8575 & 58 \\
\hline 1 & 2 & 0.9893 & 28 & 1 & 52 & 0.9931 & 17 \\
\hline 2 & 3 & 0.8628 & 53 & 3 & 53 & 0.7913 & 81 \\
\hline 2 & 4 & 0.8580 & 57 & 3 & 54 & 0.5833 & 92 \\
\hline 1 & 5 & 0.9903 & 27 & 3 & 55 & 0.8982 & 43 \\
\hline 2 & 6 & 0.8599 & 55 & 3 & 56 & 0.7377 & 88 \\
\hline 2 & 7 & 0.8663 & 50 & 3 & 57 & 0.7529 & 86 \\
\hline 3 & 8 & 0.5007 & 99 & 2 & 58 & 0.8086 & 75 \\
\hline 2 & 9 & 0.8950 & 44 & 3 & 59 & 0.7596 & 85 \\
\hline 2 & 10 & 0.8861 & 45 & 3 & 60 & 0.7469 & 87 \\
\hline 1 & 11 & 0.9954 & 8 & 1 & 61 & 0.9921 & 21 \\
\hline 1 & 12 & 0.9949 & 14 & 2 & 62 & 0.9143 & 40 \\
\hline 1 & 13 & 0.9953 & 11 & 1 & 63 & 0.9839 & 32 \\
\hline 2 & 14 & 0.9151 & 39 & 3 & 64 & 0.5247 & 97 \\
\hline 1 & 15 & 0.9938 & 16 & 1 & 65 & 0.9922 & 19 \\
\hline 3 & 16 & 0.8173 & 72 & 1 & 66 & 0.9921 & 20 \\
\hline 2 & 17 & 0.8283 & 68 & 2 & 67 & 0.9250 & 37 \\
\hline 3 & 18 & 0.8237 & 70 & 1 & 68 & 0.9972 & 1 \\
\hline 1 & 19 & 0.9951 & 13 & 2 & 69 & 0.9091 & 41 \\
\hline 1 & 20 & 0.9840 & 31 & 1 & 70 & 0.9953 & 10 \\
\hline 1 & 21 & 0.9875 & 30 & 1 & 71 & 0.9956 & 7 \\
\hline 1 & 22 & 0.9820 & 33 & 3 & 72 & 0.8273 & 69 \\
\hline 3 & 23 & 0.5984 & 90 & 3 & 73 & 0.8099 & 74 \\
\hline 2 & 24 & 0.9818 & 34 & 3 & 74 & 0.8350 & 66 \\
\hline 3 & 25 & 0.6086 & 89 & 2 & 75 & 0.9209 & 38 \\
\hline 1 & 26 & 0.9964 & 5 & 1 & 76 & 0.9928 & 18 \\
\hline 1 & 27 & 0.9911 & 25 & 3 & 77 & 0.8143 & 73 \\
\hline 3 & 28 & 0.8029 & 77 & 2 & 78 & 0.8632 & 52 \\
\hline 1 & 29 & 0.9921 & 22 & 2 & 79 & 0.9263 & 36 \\
\hline 1 & 30 & 0.9921 & 23 & 1 & 80 & 0.9964 & 4 \\
\hline 3 & 31 & 0.7883 & 84 & 2 & 81 & 0.8996 & 42 \\
\hline 2 & 32 & 0.8620 & 54 & 3 & 82 & 0.8693 & 49 \\
\hline 3 & 33 & 0.7910 & 82 & 1 & 83 & 0.9964 & 3 \\
\hline 1 & 34 & 0.9952 & 12 & 2 & 84 & 0.9502 & 35 \\
\hline 3 & 35 & 0.5022 & 98 & 1 & 85 & 0.9962 & 6 \\
\hline 1 & 36 & 0.9893 & 29 & 1 & 86 & 0.9949 & 15 \\
\hline 2 & 37 & 0.8405 & 64 & 1 & 87 & 0.9919 & 24 \\
\hline 2 & 38 & 0.8516 & 59 & 3 & 88 & 0.5747 & 93 \\
\hline 2 & 39 & 0.8659 & 51 & 3 & 89 & 0.5531 & 95 \\
\hline 1 & 40 & 0.9953 & 9 & 2 & 90 & 0.8744 & 47 \\
\hline 2 & 41 & 0.8476 & 62 & 3 & 91 & 0.5929 & 91 \\
\hline 3 & 42 & 0.7893 & 83 & 3 & 92 & 0.5551 & 94 \\
\hline 2 & 43 & 0.8228 & 71 & 2 & 93 & 0.8853 & 46 \\
\hline 2 & 44 & 0.8510 & 60 & 3 & 94 & 0.5513 & 96 \\
\hline 3 & 45 & 0.8036 & 76 & 2 & 95 & 0.8581 & 56 \\
\hline 2 & 46 & 0.8499 & 61 & 3 & 96 & 0.7942 & 80 \\
\hline 3 & 47 & 0.7963 & 79 & 2 & 97 & 0.8469 & 63 \\
\hline 2 & 48 & 0.8707 & 48 & 2 & 98 & 0.8303 & 67 \\
\hline 1 & 49 & 0.9909 & 26 & 3 & 99 & 0.8028 & 78 \\
\hline 1 & 50 & 0.9968 & 2 & & & & \\
\hline
\end{tabular}

Note: Size 1=small, 2=medium,3=big hospitals. 